\title{
"Smart" sprayer technology provides environmental and economic benefits in California orchards
}

\author{
by Durham K. Giles, Parry Klassen, Franz J.A \\ Niederholzer and Daniel Downey
}

\section{Spray applications of pesticides to} orchards are a common cultural practice; however, they present environmental concerns due to emissions of volatile organic compounds (VOCs), runoff that can allow pesticides to enter waterways, and spray drift onto nontarget areas. Advanced sprayer technology can address these concerns and improve application efficiency by reducing the amount of spray that does not reach the target. Target-sensing sprayers were evaluated in multiseason experiments.

They reduced pesticide application rates by $15 \%$ to $40 \%$ and nontarget orchard-floor deposition by $5 \%$ to $72 \%$, providing significant environmental and economic benefits.

n California, orchard crops receive
dormant and in-season applications of agrochemicals, including organo-
phosphates and pyrethroids to contro insect pests and fungicides to control diseases. For dormant applications, the winter rainfall, particularly storms, increases the potential for pesticides to reach rivers and tributaries (Kuivila and Foe 1995). Brady et al. (2006) reported the off-site movement and detection of two pesticides (diazinon and esfenvalerate) in California rivers. Werner et al. (2004) reported toxicity to several aquatic species when exposed to storm-water runoff collected in orchards following dormant-season applications of diazinon or esfenvalerate. These findings, coupled with concerns about the toxicity of organophosphate insecticides, have led to increased regulatory restrictions on their application in orchards.

Concurrently, concern over air pollution is increasing. The U.S.

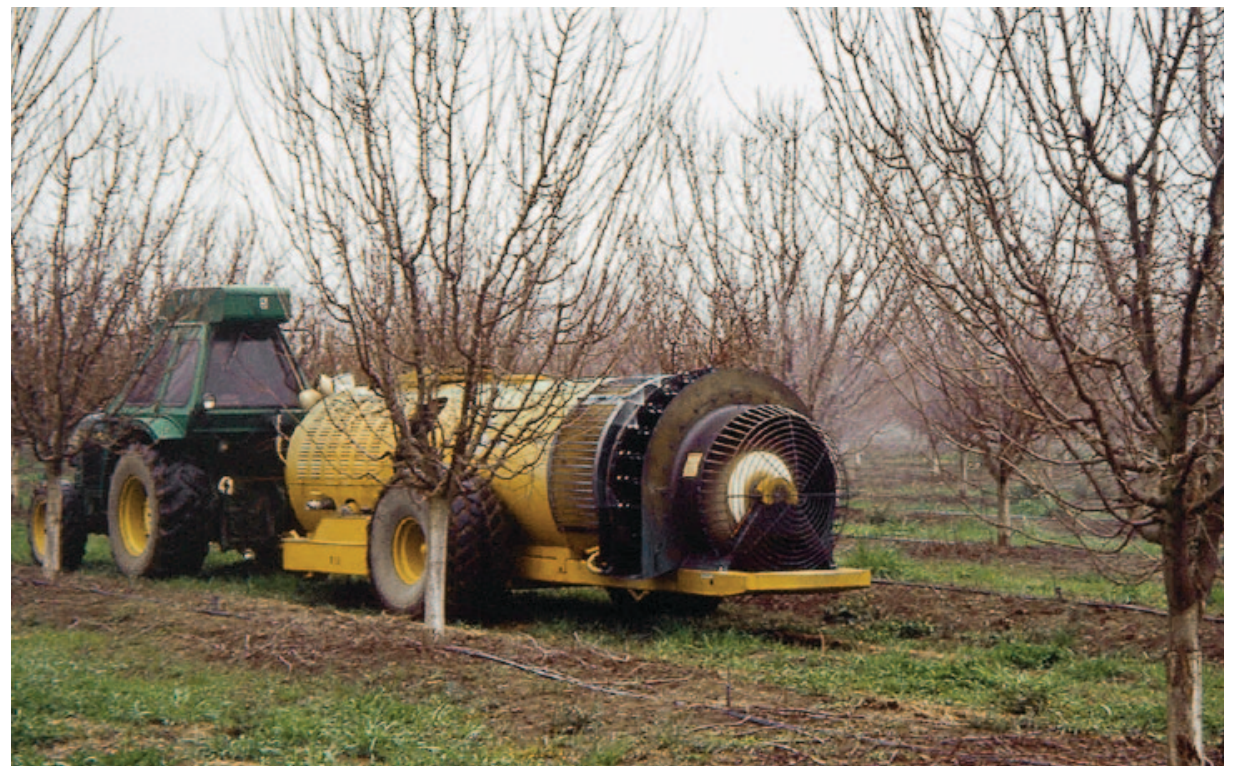

A commercial sprayer retrofitted with a target-sensing spray system applies dormant spray in a prune orchard near Chico. These "smart" systems only apply sprays where a tree is detected.

Environmental Protection Agency (EPA) classifies portions of the Central Valley as extreme nonattainment areas for the 8-hour ozone standard. The California Air Resources Board lists 21 counties, or portions of counties, as nonattainment areas (CARB 2010). Ozone is formed through the interaction of nitrogen oxides and volatile organic compounds (VOC). The California Department of Pesticide Regulation targeted a 20\% reduction in VOC emissions from pesticide usage by 2010 (USDA 2009). The pesticides most commonly applied in dormant orchard spray applications are typically formulated as emulsifiable concentrations, often tank-mixed with dormant oils, which are identified as contributors to VOC emissions.

To reduce both air and water contamination resulting from orchard applications of pesticides while maintaining their pest control benefits, we examined candidate technologies that could meet the environmental goals yet remain attractive to growers. Often, improved technology to reduce emissions provides no direct economic benefit to the user or grower; however, with advanced agricultural spraying equipment, reducing pesticide use rates can provide potential economic benefits, primarily from pesticide savings but also from improved efficiency.

\section{Efficiency of orchard spraying}

Previous studies have investigated orchard spraying and found significant opportunities for improving the process. Much of the released pesticide does not reach the target trees. Seiber et al. (1993) measured deposition from dormant spraying of diazinon in a peach orchard and found that $88 \%$ of recovered pesticide was on the orchard floor instead of the trees. Cross et al. $(2001 a, b)$ investigated the effects of spray droplet size and application volumes of 10 to 80 gallons per acre (94 to 748 liters per hectare) on spray deposition in an apple orchard; $43 \%$ to $61 \%$ of the applied spray was lost to ground deposit within 15 feet (4.6 meters) of the row being sprayed. The study also concluded that for most typical orchard applications, the liquid volume rate (gallons per acre) is so large that differences in spray droplet size have little effect on spray deposition, since the trees are essentially saturated with liquid and any additional spray volume simply runs off the tree foliage. Similarly, once the application rates are above the saturation level, the actual 
amount of applied volume has little effect on spray deposition. These findings suggest that simple changes in spray nozzle selection and setup may assist in reducing off-target movement but may not achieve significant improvements in application efficiency and pesticide use rates.

A study of semidwarf apples and pears measured spray deposits at an application rate of 50 gallons per acre (468 liters per hectare) (Vercruysse et al. 1999). Before bloom, approximately $44 \%$ of the applied spray was measured as spray drift or ground deposit.

\section{The basic concept of the sprayer operation is to apply the spray only to the target trees, allowing the sprayer to turn off between trees or in areas where trees are missing.}

After bloom, 32\% of the spray failed to deposit on the crop. The authors concluded that during early growth stages, ground deposit was considerable and the presence of foliage on trees reduced airborne drift by $50 \%$ to $80 \%$. A study in vineyards concluded that $37 \%$ to $62 \%$ of applied spray failed to deposit on target leaves (Pergher et al. 1997). An Ohio study determined that $57 \%$ of the spray

applied to dwarf apples was deposited meters) of the orchard (Fox et al. 1990).

\section{Sensor-equipped orchard sprayers}

Sensor-equipped orchard sprayers, multiple ultrasonic or optical detectors to sense the presence or absence of trees, and they activate the spray

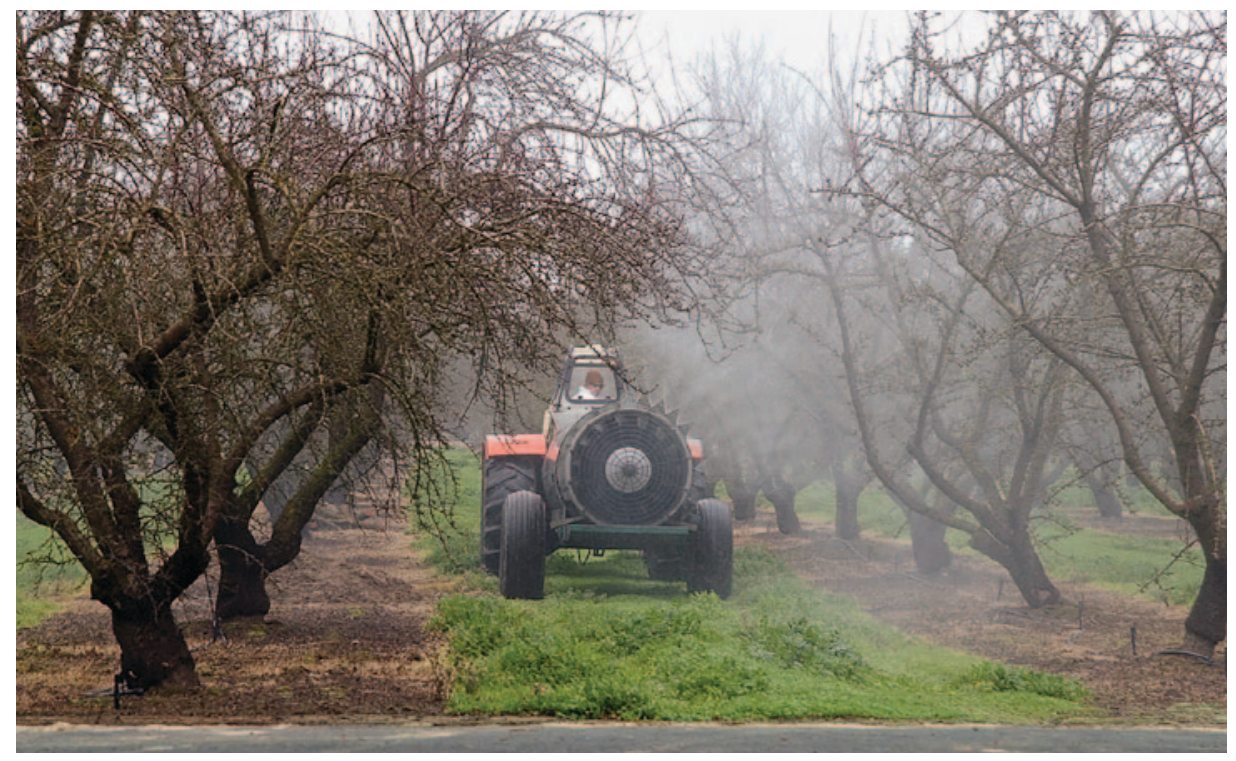

In an almond orchard near Modesto, a target-sensing sprayer travels between rows.

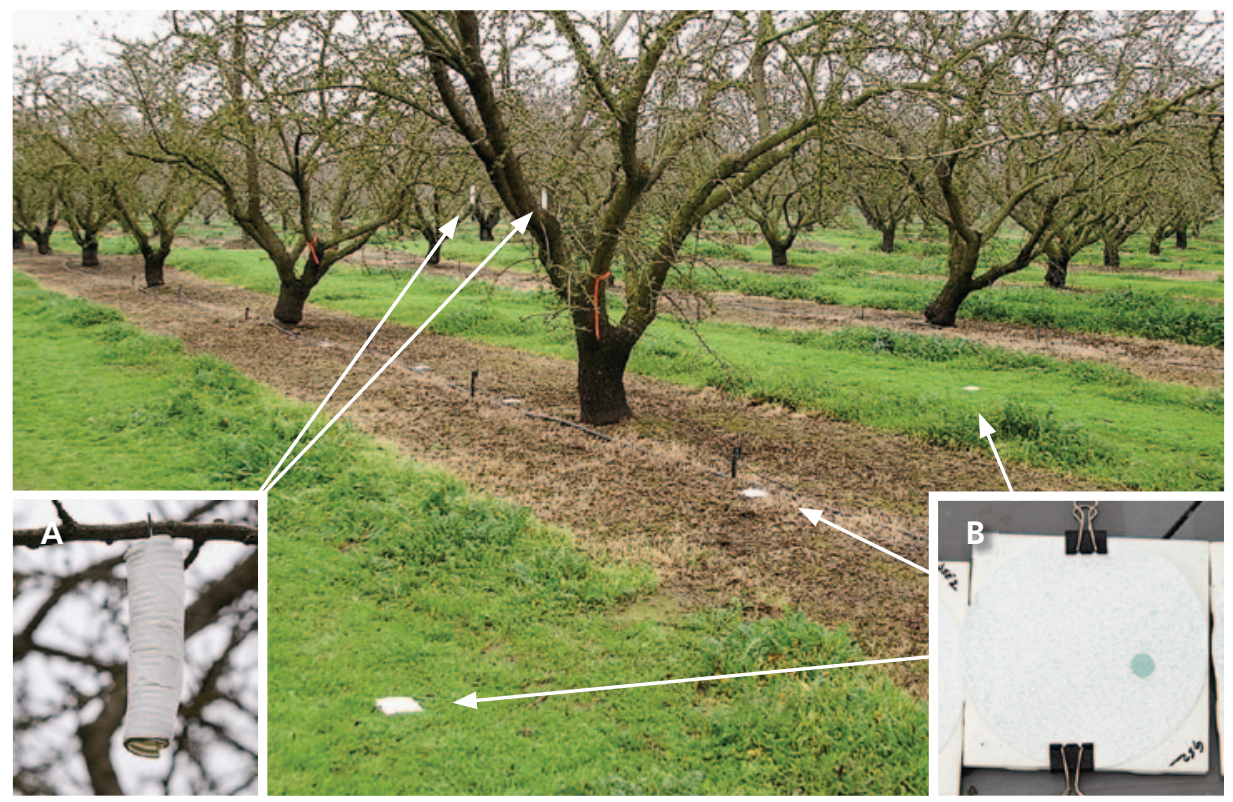

To monitor the tree and ground deposition of spray applications, (A) 1-inch-diameter cylinders fitted with fiber filters were suspended from almond trees at different heights and (B) 4.25-inch glass filters supported by flat ceramic tiles were laid on the orchard floor. on the ground within 150 yards (137 sometimes called "smart" sprayers, use nozzles only when a target is present in the spray zone corresponding to each sensor. While still considered a new technology, the technique was developed more than 20 years ago (Giles et al. 1987) and has been on the market for over a decade. The initial patents on the ultrasonic systems have expired, allowing commercial competition among designs, prices and vendors and providing more options for growers.

The basic concept of the sprayer operation is to apply the spray only to the target trees, allowing the sprayer to turn off between trees or in areas where trees are missing, and to turn off portions of the sprayer where trees are short or foliage is sparse. Giles et al. (1987) found an average savings of $28 \%$ to $34 \%$ and $36 \%$ to $52 \%$ for applications to in-season peaches and apples, respectively, using the system. The study found that spray-volume savings were dependent on crop characteristics; when used in younger, smaller trees or in mature orchards with high proportions of replanted (young) trees, the savings increased correspondingly.

In principle, these sprayers maintain spray deposition equivalent to conventional sprayers on the target trees, while reducing wasted spray that would deposit on nontarget orchard floors and contribute unnecessarily to both VOC emissions and, potentially, runoff and water contamination. Moreover, reductions in applied pesticide provide economic returns to growers, helping to defray the capital investment in the sprayer.

\section{Testing smart sprayers}

The objective of these studies was to determine how the use of smart 
sprayers provides benefits for reducing pesticide use and nontarget deposition. Particular emphasis was on reducing ground deposit and runoff during dormant-season spraying. Additionally, the economic return was projected for grower investments in the technology. The ultimate goal of the research was to reduce the amount of pesticide used, as well as the off-target movement of orchard-applied pesticides.

Three field studies were conducted in commercial orchards using commercial equipment, and with applications made by growers. Studies were conducted over three seasons, using registered insecticides applied during the dormant seasons. All applications were part of the cooperating growers' integrated pest management (IPM) and spray programs. Two studies addressed the reduction in application rate and ground deposit (Downey and Giles 2005), and the final study addressed the reduction of pesticide runoff from an orchard (Brown et al. 2008). All three studies compared the effects from conventional and sensor-equipped sprayers.

Chico prunes. The first experiment was conducted in a commercial prune orchard near Chico with trees approximately 20 years old. The spray application of diazinon was made with an engine-driven, axial flow sprayer (Model D2/40, Air-O-Fan, Reedley, Calif.), with an application rate of 2 pounds per acre (2.24 kilograms per hectare). Trees were approximately 12 feet (3.7 meters) high and planted at 160 trees per acre (395 trees per hectare) with row spacing of 15 feet (4.6 meters). The conventional spray application rate was 100 gallons per acre (935 liters per hectare) at a ground speed of 2 miles (3.2 kilometers) per hour. An ultrasonic control system (Smart Spray, DurandWayland, LaGrange, Ga.) was retrofitted to the machine.

Deposition samples were collected on glass fiber filters placed on flat plates within the target trees and on the ground between and within tree rows. For each treatment, four trees were sampled with four sample points per tree. Six ground samples were taken for each sprayer treatment. The area for each treatment was five rows wide by 0.25 mile (0.4 kilometer) long, equal to

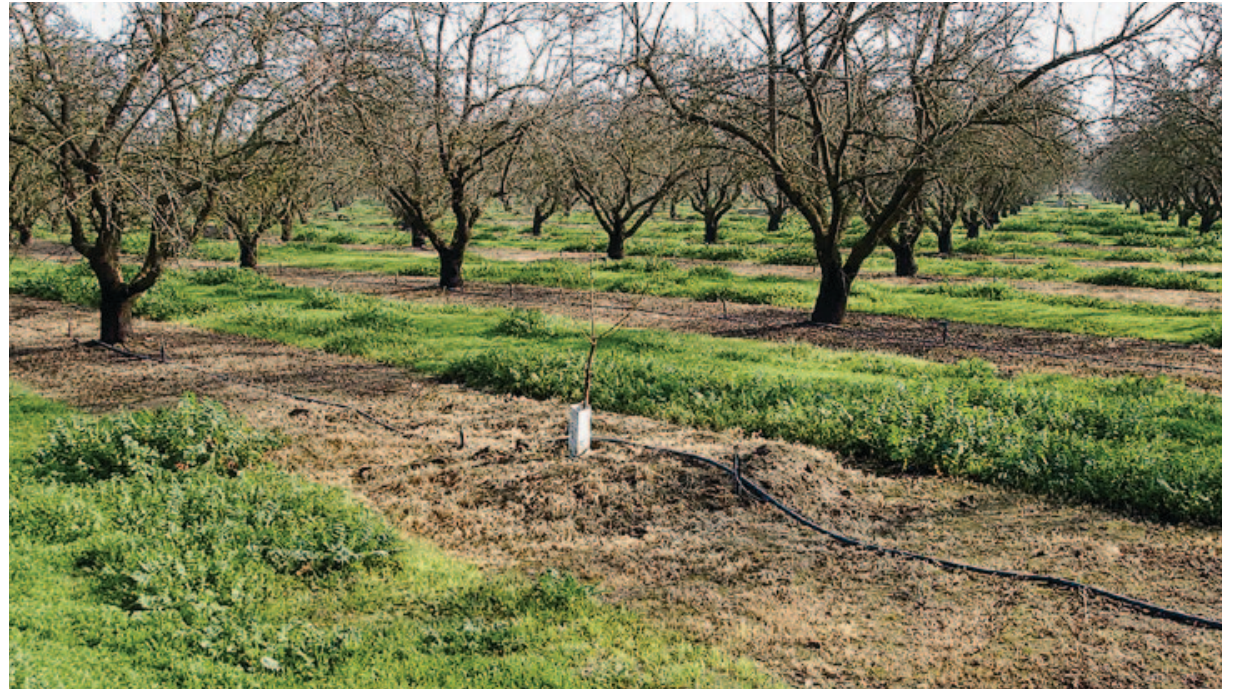

The smart sprayer skips the spot where a new almond tree is planted, significantly reducing the amount of spray deposited on the ground. If necessary, growers can use the smart sprayer's manual override to treat small plantings, or they can be treated by hand.

approximately 2.25 acres (0.9 hectare). After spraying, the filter samples were recovered from the trees and ground, preserved in airtight bags, placed on ice and transported to the California Department of Food and Agriculture (CDFA) lab for chemical analysis.

Modesto almonds. The second experiment was conducted in a mature commercial almond orchard near Modesto, where the majority of trees were approximately 20 years old and planted on a 23 -foot (7-meter) diamond pattern. Each treatment (sensor-equipped versus conventional spraying) was applied to approximately 5.5 acres (2.2 hectares). The conventional application was a dormant spray of copper, oil and chlorpyrifos at the standard rate of 2 pounds active ingredient per acre (2.24 kilograms per hectare) and 100 gallons per acre (935 liters per hectare). The application was made using an AF500 Smart Sprayer (Durand-Wayland, LaGrange, Ga.) at 2.75 miles (4.4 kilometers) per hour.

Deposition samples were collected on glass fiber filters placed on cylindrical tubes within the target trees (four trees sampled) and on ceramic tiles positioned on the ground between and within tree rows, totaling eight ground samples per treatment. After spraying, the filter samples were recovered from the trees and ground, preserved in airtight bags, placed on ice and transported to the CDFA lab for chemical analysis.
Oroville prunes. The third field experiment was conducted in a 20 -yearold mature prune orchard near Oroville where diazinon had historically been applied during the dormant season. The test orchard was approximately 40 acres (16 hectares), and the trees were planted on elevated berms. Tree spacing was 18 feet (5.5 meters) within the row, row spacing was 18 feet ( 5.5 meters), row length was 450 feet (137 meters) and density was 130 trees per acre (321 trees per hectare). The orchard was landplaned for surface irrigation.

The sprayer used was a power-takeoff-driven (PTO), axial-flow fan orchard sprayer (AF505CPS, Durand-Wayland, Lagrange, Ga.). The ground speed for all applications was 3 miles (4.8 kilometers) per hour. The application rate of diazinon was 2 pounds per acre (2.24 kilograms per hectare) applied as an emulsifiable concentration. The conventional application rate of tank mix was 100 gallons per acre (935 liters per hectare). Each spray treatment was replicated six times, and 12 independent plots were randomly established within the orchard for the entire study. Each treatment plot consisted of seven row middles (corresponding to eight tree rows) running the length of the orchard.

After the spray application, simulated rainfall was applied to the sample rows, resulting in surface-water runoff. Rainfall was simulated using impact sprinklers set on risers above the 
orchard floor. A simulated rainfall rate was applied at approximately 0.25 inch ( 0.64 centimeter) per hour. This rate was used during the surface-water runoff trials; simulated rainfall occurred for 2 hours and 40 minutes after each spray application. Approximately 0.7 inch (1.8 centimeters) of rainfall was applied for each treatment. The rainfall event for the study was initiated 24 hours after the spray applications were completed. Runoff water samples were collected using apparatus and methods described by Brady et al. (2006). The automated system measured the volume of runoff and sequentially removed water samples for analysis (Brown et al. 2008).

\section{Less pesticide applied}

In every field experiment, use of the sensor-equipped sprayer (with control system) resulted in spray savings, meaning that less pesticide was applied (table 1). The mature prune orchard near Chico had the least spray savings (15\%). Its relatively dense and uniform trees - which presented a wall of foliage with smaller gaps between trees reduced potential savings that the smart sprayer could achieve. Savings from smart sprayers are generally proportional to openings and gaps in the tree rows (Giles et al. 1987). In the mature almonds near Modesto - which had large trees with larger gaps, especially between the lower portions - there was a $22 \%$ reduction in applied spray. Finally, the mature prunes near Oroville, with a less-dense planting and wider gaps between trees, resulted in a $40 \%$ reduction.

These results reinforce previous research showing that savings from sensor-triggered spraying are related to orchard characteristics. Additionally, the smart-sprayer systems allow the operator to adjust the sensitivity and overspray settings; different applicators may use different settings, resulting in more or less savings. Applicators tend

\begin{tabular}{|c|c|c|}
\hline \multirow[b]{2}{*}{ Orchard } & \multicolumn{2}{|c|}{ Application } \\
\hline & Conventional & Smart spray* \\
\hline & \multicolumn{2}{|c|}{ gallons/acre (liters/hectare) } \\
\hline Prunes (Chico) & $100(935)$ & 85 (794) \\
\hline Almonds (Modesto) & $100(935)$ & 78 (729) \\
\hline Prunes (Oroville) & $100(935)$ & $60(561)$ \\
\hline
\end{tabular}

\begin{tabular}{|c|c|c|}
\hline \multirow[b]{2}{*}{ Orchard } & \multicolumn{2}{|c|}{ Application } \\
\hline & Conventional & Smart spray \\
\hline & \multicolumn{2}{|c|}{ micrograms $/ \mathrm{cm}^{2}$} \\
\hline Prunes (Chico) & 5.2 & 4.9 \\
\hline Almonds (Modesto) & $11.3 a *$ & $3.2 b$ \\
\hline Prunes (Oroville) & $24.2 a$ & $9.9 a$ \\
\hline
\end{tabular}

to be conservative, setting the control's sensitivity to overspray in order to prevent underspraying portions of trees.

Deposition on the trees was maintained at levels equivalent to or even greater than conventional spraying (data not shown). In the more-dense prune orchard, the target-sensed sprayer reduced ground deposit by $5 \%$ versus the conventional sprayer (table 2). This result indicates that the dense spacing of prune trees in this Chico orchard captured the majority of spray onto trees irrespective of application type. For the almond and moreopen prune orchards, the reductions were $72 \%$ and $59 \%$, respectively. The decreased ground deposition in these two orchards shows that increased tree spacing along rows minimizes ground deposition when smart-spray technology is used. When concentrations of pesticide were measured in the runoff water of the open prune orchard near Oroville (table 3), the reduction from sensor-controlled spraying was 54\%,

\begin{tabular}{|c|c|c|c|}
\hline Application & Concentration & Runoff volume & Diazinon \\
\hline & micrograms/liter & gallons (liters) & milligrams \\
\hline Conventional & $505 a *$ & $976(3,694)$ & $1,889 a$ \\
\hline Smart spray & $282 b$ & $854(3,232)$ & $911 \mathrm{~b}$ \\
\hline
\end{tabular}

similar to the reduction in ground deposit.

\section{Reducing costs}

Spray application technology reduces the amount of pesticide applied while maintaining the necessary levels of deposition on trees, providing direct economic benefits to growers while at the same time providing significant environmental benefits. Improved equipment productivity is an added benefit. By reducing the application rate of the pesticide mix, each tank load of material covers a greater land area, effectively reducing the number of refills, ferry trips and time spent spraying each orchard. This provides an additional economic return to the grower by reducing labor and fuel costs.

While the sensor technology provides environmental and pesticide savings benefits to the grower, the decision to invest in a new technology is often taken cautiously and is based on projections of economic return. The economic returns to the grower would come from two sources: first, the reduction in pesticide use, and second, improved equipment productivity.

The reduction in pesticide costs can be substantial. UC Cooperative Extension publications on the costs to establish and produce orchard crops were used to estimate pesticide costs per acre in common California orchard crops (Freeman et al. 2008). For Sacramento Valley almonds, pest control sprays (material only for diseases and insects) were estimated at \$233 per acre ( $\$ 575$ per hectare). Similarly, the cost for San Joaquin almonds was estimated at $\$ 203$ per acre $(\$ 500$ per hectare); for Sacramento Valley prunes, $\$ 149$ per acre (\$368 per hectare); and for San Joaquin peaches, $\$ 283$ per acre $(\$ 700$ per hectare). These estimates are for material only and do not include variable application costs including labor and fuel, which we estimated at $\$ 9.50$ to $\$ 10.00$ per acre $(\$ 23.50$ to $\$ 24.70$ per hectare) for almonds and similar crops based on $\$ 2$ per gallon ( $\$ 0.53$ per liter) for diesel fuel.

Based on the results of the field tests, we assumed materials savings of $20 \%$ and operating-cost savings of $10 \%$. This resulted in a $\$ 1$ per acre $(\$ 2.47$ per hectare) operating-cost savings 
and material cost savings of $\$ 57, \$ 47$, $\$ 41$ and $\$ 30$ per acre $(\$ 141, \$ 116, \$ 101$ and $\$ 74$ per hectare) for San Joaquin peaches, Sacramento Valley almonds, San Joaquin almonds and Sacramento Valley prunes, respectively.

The current cost of a retrofit spray sensor and control system is approximately \$15,000 (Niederholzer 2009). A rule of thumb in the agricultural electronics industry is that a new product has a reasonable chance of adoption and sales success if the payback period is 2 years or less. With the estimated purchase price and estimated economic savings, a 2-year payback would be achieved for prune, almond and peach growers spraying 250, 160 and 130 acres (101, 65 and 53 hectares) per year. For growers with larger areas, the payback period would be proportionally less.

\section{Investing in new technology}

Use of the smart-spray technology is growing in the industry but remains a small part of the spraying equipment market. A further incentive for growers to invest in the technology is the U.S. Department of Agriculture's Environmental Quality Incentives Program (EQIP), authorized by federal law in 2002 (and reauthorized in the 2008 Farm Bill), which provides a voluntary conservation program for farmers and ranchers to promote agricultural production and environmental quality as compatible national goals. EQIP offers financial and technical assistance to eligible participants to install or

\section{References}

Brady JA, Wallender WW, Werner I, et al. 2006. Pes ticide runoff from orchard floors in Davis, California, USA: A comparative analysis of diazinon and esfenvalerate. Ag Ecosyst Env 115(1-4):56-68.

Brown DL, Giles DK, Oliver MN, Klassen P. 2008. Targeted spray technology to reduce pesticide in runoff from dormant orchards. Crop Prot 27(3-5):545-52.

[CARB] California Air Resources Board. 2010. Area Designations for the Federal 8-Hour Ozone Standard. hwww.arb.ca.gov/desig/8-houroz/8-houroz.htm (accessed 3/3/2010).

Cross JV, Walklate PJ, Murray RA, Richardson GM. 2001a. Spray deposits and losses in different sized apple trees from axial fan orchard sprayers: 1. Effects of liquid flow rate. Crop Prot 20(1):13-30.

Cross JV, Walklate PJ, Murray RA, Richardson GM. $2001 \mathrm{~b}$. Spray deposits and losses in different sized apple trees from axial fan orchard sprayers: 2 . Effects of spray quality. Crop Prot 20(4):333-43.

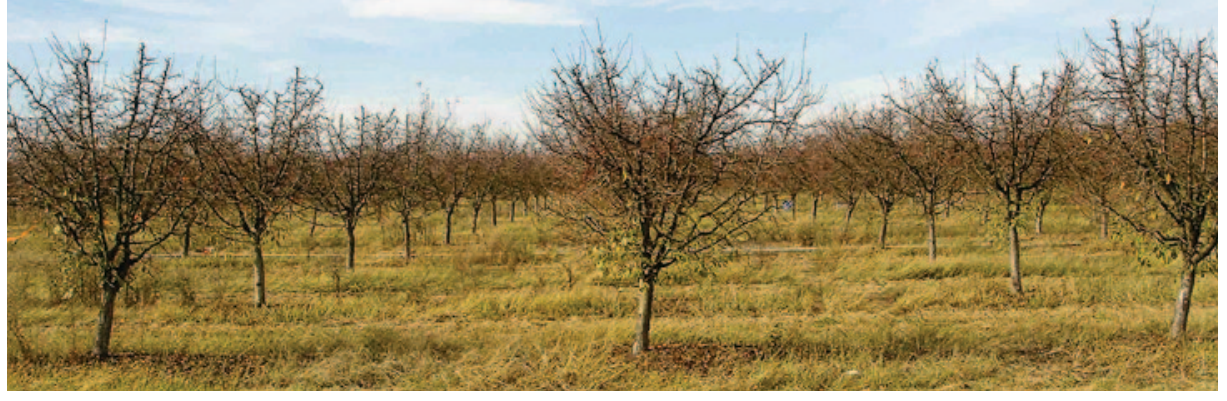

In a mature prune orchard near Oroville, the smart sprayer reduced application rates by $\mathbf{4 0}$ gallons per acre $(40 \%)$ when compared with the conventional sprayer, and pesticides in the runoff water were $54 \%$ lower.

implement structural and management practices on eligible agricultural land.

In particular, the California program includes an Air Quality Enhancement Program that is "designed to provide cost share incentives and technical assistance to farmers and ranchers for installation of practices which reduce air pollution" (USDA 2011). The program targets statewide "airsheds" where levels of ozone, VOC or fine particulate matter have been classified as serious, severe or extreme nonattainment areas as defined by the U.S. EPA. The EQIP program provides financial and technical assistance to address nitrous oxide, VOC and particulate matter emissions. For example, it states: "The application of pesticides through sprayers produces VOC emissions. Growers can reduce these targeted VOC emissions by adopting new precision spray application technologies."

The program guidelines further state: "Precision spray technology used must provide at least a $20 \%$ reduction in spray, based on peer-reviewed research documentation" (USDA 2011). In 2011, the financial incentive for these precision spray technologies is $\$ 30$ per acre (\$74 per hectare) for a maximum of 500 acres (202 hectares) - a total of $\$ 15,000$ per contract. The amount is sufficient to adequately cover the cost of purchasing a typical target-sensing system for an orchard sprayer.

D.K. Giles is Professor, Department of Biological and Agricultural Engineering, UC Davis; P. Klassen is Executive Director, Coalition for Urban/Rural Environmental Stewardship, Dinuba, Calif.; F.J.A. Niederholzer is Orchard Systems Farm Advisor, UC Cooperative Extension, Sutter and Yuba counties; and D. Downey is Associate Project Engineer, Department of Biological and Agricultural Engineering, UC Davis.

Partial funding was provided through an agreement with the California State Water Resources Control Board. The Central Valley Water Quality Control Board provided initial project support. Portions of the work were conducted with a grant administered through the Coalition for Urban/Rural Environmental Stewardship, a nonprofit organization. This project was also supported by Agriculture and Food Research Initiative Competitive Grant no. 2009-55112-05217 from the USDA National Institute of Food and Agriculture. Our thanks to Sam Judah and DurandWayland for use of the sprayers.
Downey D, Giles DK. 2005. Reducing orchard spray rates and ground deposit by using tree sensors and sprayer control. Ann Rev Ag Eng 4:229-36.

Fox RD, Brazee RD, Reichard DL, Hall FR. 1990 Downwind residue from air spraying of a dwarf apple orchard. Trans ASAE 33(4):1104-8.

Freeman MW Viveros MA, Klonsky KM, De Moura RL. 2008. Sample Costs to Establish an Almond Orchard and Produce Almonds. UC Cooperative Extension. Pub No AM-VS-08-1. http://coststudies.ucdavis.edu.

Giles DK, Delwiche MJ, Dodd RB. 1987. Control of orchard spraying based on electronic sensing of target characteristics. Trans ASAE 30(6):1624-30.

Kuivila KM, Foe CG. 1995. Concentrations, transport and biological effects of dormant spray pesticides in the San Francisco estuary, California. Env Toxicol Chem 14(7):1141-50.

Niederholzer F. 2009. Smart sprayers make sense for orchards. Western Farm Press, April 15.

Pergher G, Gubiani R, Tonetto G. 1997. Foliar deposition and pesticide losses from three air-assisted sprayers in a hedgerow vineyard. Crop Prot 16(1):25-33.
Seiber JN, Wilson BW, McChesney MM. 1993. Air and fog deposition residues of four organophosphate insecticides used on dormant orchards in the San Joaquin Valley, California. Env Sci Technol 27(10):223643.

[USDA] US Department of Agriculture. 2009. Fact sheet - Pest Management. Environmental Quality Incentives Program. Natural Resources Conservation Service. www.ca.nrcs.usda.gov/programs/eqip/2009/ cig-b-documents.html.

USDA. 2011. Environmental Quality Incentives Program (EQIP): California Air Quality Enhancement Program. Natural Resources Conservation Service. www. ca.nrcs.usda.gov/programs/airquality/airquality.html.

Vercruysse F, Steurbaut W, Drieghe S, Dejonckheere W. 1999. Off target ground deposits from spraying a semi-dwarf orchard. Crop Prot 18(9):565-70.

Werner I, Zalom FG, Oliver MN, et al. 2004. Toxicity of storm-water runoff after dormant spray application in a French prune orchard, Glenn County, California, USA: Temporal patterns and the effect of ground covers. Env Toxicol Chem 23(11):2719-26. 